\title{
The Great War and All That in A Hundred Doors by Michael Longley
}

\author{
Elisabet Delattre \\ Centre for Irish Studies, University of Lille3, France
}

Copyright (c) 2015 by Elisabet Delattre. This text may be archived and redistributed both in electronic form and in hard copy, provided that the author and journal are properly cited and no fee is charged for access.

\begin{abstract}
The Great War has featured regularly in Michael Longley's poetry, for personal, family, aesthetic and political reasons. His collection published in 2011 under the title A Hundred Doors contains a number of poems relating to his father and the so-called War Poets, in connection with others in which love and nature, life and death are also dominant themes. This article will show how, as elsewhere in his poetry, everything is interrelated, "the nature poetry", in Longley's words, "fertilizing the war poetry".
\end{abstract}

Key Words. Michael Longley, Great War, father-figure, war poets, elegy, sonnet, life, death, nature, nurture.

Resumen. La Gran Guerra aparece regularmente en la poesía de Michael Longley, por razones familiares, estéticas o políticas. El volumen A Hundred Doors, publicado en 2011, contiene poemas relacionados con su padre y los denominados 'poetas de guerra', junto a otros que abordan también el amor, la naturaleza, la vida y la muerte. El artículo mostrará la interrelación de temas que caracteriza toda su obra poética, en la que, en palabras del propio Longley "la poesía de la naturaleza fertiliza la poesía bélica".

Palabras clave. Michael Longley, Gran Guerra, figura paterna, poetas de guerra, elegía, soneto, vida, muerte, naturaleza, crianza.

Who can bring peace to people who are not civilised? All of these people, alive or dead, are civilised.

(Michael Longley, The Weather in Japan)

In an interview granted in 2011, on the occasion of the publication of A Hundred Doors, Michael Longley expressed the wish that his work would ultimately "look like four really long poems, a very long love poem, a very long meditation on war and death, a very long nature poem and a playful poem on the art of poetry". Using the plant image, he wanted "the strands both to entwine with each other, and every now and again to emerge as separate" (Moore). Indeed, if nature, love and life are major aspects which intertwine sometimes inextricably so, in a kind of "Noah's ark" (Brown 2002: 92), violence and war have also pervaded his poetry since he began writing. As he himself acknowledged, "the two World Wars were part of [his] family's history before they became part of [his] imaginative landscape" (Brown: 94). Longley's approach is underlined by the fact that everything is interconnected and this, to quote Elmer Kennedy-Andrews, is what characterizes "Longley's aesthetic" expressed through "his use of metaphor, his techniques of fusion, juxtaposition and parallelism, his fluid handling of time, place and identity, his self-conscious 
intertextuality" (Kennedy-Andrews 2000: 7475).

The collection published under the title $A$ Hundred Doors in 2011, is composed of sixtysix poems ranging from two lines up to fortyfour. The title of the book refers to "Our Lady of a Hundred Doors" on the island of Paros, considered to be the oldest Byzantine Church in Greece, which the poet had visited during his sojourns in that part of the Aegean Sea, and which he calls his "muse" (15) in an eponymous poem contained in the collection. This paper aims at showing that while $A$ Hundred Doors contains most of the characteristics of Longley's earlier poetry it evinces a somewhat lighter utterance. If the tone has become simpler and maybe more insouciant, there is still a deep awareness of the fragility of nature and life. My analysis will follow three main themes that in fact are interlinked and echo each other: war and more particularly the First World War, then life and its corollary death in the shape of the poet's human environment and finally the context of nature which the poet has found in the west of Ireland.

\section{The No Man's Land of War}

Michael Longley's father is a recurring figure in his poetry and many of his son's poems celebrate his courage in the trenches during the First World War. These poems are often associated with evocations of poets such as Edward Thomas, Wilfred Owen, Isaac Rosenberg, Robert Graves, the so-called "war poets", who fought in Northern France and some of whom died in action there. Moreover, the two World Wars and his reading of the war poets framed Longley's view of the "Troubles" in his native country, in so far as they have given him a perspective on the violence which more generally pervades his poetry.

In 2013, Longley edited a selection of poems by Robert Graves. The phrase included in the title of this article ("and all that") partly refers to Graves's autobiography, Good-Bye to All That, published in 1929. In this work, its author relates his memories of World War I, more precisely the battle of Loos and the Battle of the Somme in which he took part as an officer in the Royal Welsh Fusiliers, and during which he had mistakenly been declared as killed in action. As a matter of fact, Graves, "more than was the case with the other war poets", did not make an indictment of the war but, to quote Longley, "professed an open-faced, almost naïve regimental loyalty". Graves's poetry has been an important source of inspiration and a model, confining to veneration as Longley recalled in the same introduction: "Graves lays down the law majestically [...]. Yet his line is flexible, at times improvisatory, jazzy even". Michael Longley acknowledges the importance of Graves's prose work previously mentioned on his own evolution and also the fact that Graves's portrayal of "the psychic quagmire" of the trenches echoed what he remembered of his father's infrequent recollections.

As Barry Sloan (2012) has demonstrated in an article published in Estudios Irlandeses, Richard Longley has played a major role in his son's poetry, and will most likely continue to do so. Indeed, Longley's father is evoked in each collection, from the poem "In Memoriam" published in No Continuing City in 1969, or "Wounds" in the next collection An Exploded View in 1973 to "Citation" in A Hundred Doors. "In Memoriam" is considered as the first of a lifelong sequence of elegies for his father as well as what he called in an interview granted in 2003, "the other boy-soldiers" (Randolph 2003: 297). For five decades, the poet declares having literally been following in his footsteps as well as in those of Graves.

As Longley declared in interview, his father had joined the London Scottish as a boy-soldier in 1914 and miraculously survived, but his death a few decades later, in 1960, was a direct consequence of the severe wound he received then, and he had become a natural focus. The Military Cross awarded Lt (A/Capt.) Longley at the age of twenty for outstanding military action in the face of the enemy but which his son became acquainted with much later, is the subject of the poem, "Citation": here the poet has reproduced verbatim, the text of the official citation, in the form of a sonnet, ironically commenting on the poetic talents of its author: "It is like a poem. It is better than a poem, / The citation for my father's Military Cross" (38). However, the solemnity of the tone is in contrast with the preceding poem entitled "Bumpf", a thirteen-line poem full of hyphens imposing a syncopated rhythm and dealing with the crude facts of life: "There was no bumpf for 
Tommies / In the shithouse [...] / Nothing to wipe your arse with / Except letters from home [...] / And there was no grass either" (37).

The eleven poems explicitly devoted to the First World War start with an elegy in honour of gunner William Longley, a namesake or a very distant cousin whose grave the poet visited by chance in the Orkneys. This soldier died accidentally on board HMS Collingwood in 1918 and therefore was not killed in the trenches, a sort of collateral damage. The tone used is commiserating towards this "accidentprone" young man, "ill at ease / In the corditerisky gun / Turret" (36). Throughout most of these poems, one notices an awareness of the fact that violence is innate to mankind, as René Girard has demonstrated in La Violence et le sacré: "violence cannot be stopped or stabilized so long as it remains present among men, as long as it constitutes an issue both absolute and void, identical to divinity" (Girard $1972: 225){ }^{1}$ The function of the poet would then be to point out, through the use of metaphor, this fundamental condition and try to denounce all the atrocities committed.

As Edna Longley wrote in her annotated edition of Edward Thomas's poetry, the war is "a shifting presence as Muse, context, horizon, and shaping force" (Longley 2008: 17), a remark which might as well be applied to Longley's poetry. However, Michael Longley has also stressed the danger of putting labels which can be restrictive in the case of these poets who fought in the Great War and wrote about its horrors: "Their poems are about everything, about life as well as death" (Brown: 94). And this is the case with Longley's poetry, as we shall see in the second part of this paper.

\section{Life and Death}

Music is part and parcel of man's activities and accompanies the various stages of one's life and its inevitable corollary which is death. It also accompanies the poet who loves listening to music while composing his poems: "I believe in the singing line in poetry, in verbal melody. So great music is bound to stimulate that impulse. I believe that the calculating side

1. "tant que la violence demeure présente entre les hommes, tant qu'elle constitue un enjeu à la fois total et nul, identique à la divinité, elle ne se laisse pas immobiliser." Translation mine. of writing should be balanced with an openness to improvisatory possibilities" (Brown: 94-5). The poem "Prelude" which precedes "A Hundred Doors" refers to the music of Bach heard by the poet's inner ear, a piece of music he associates with eternity and the clarity of the sound made by cascading water. Elsewhere, the music of Robert Schumann will accompany the evocation of a "musical friend" whose death is commemorated, along with others who are honoured by the poet for their achievements in the field of art.

Thus, the last elegy, in the form of a sonnet this time, celebrates the surrealist painter Colin Middleton by giving an account of "his last painting" (46) which he names "White Farmhouse". The poet recalls that Colin Middleton - who died in 1983 and was already the dedicatee of "A Working Holiday" in the first collection, No Continuing City published in 1969 - , was a friend of his when he was young. Middleton is preceded by Raymond Piper, $^{2}$ the renowned painter of Ireland's wild flowers, especially orchids, who died in Belfast in September 2007 at the age of 84, and is the dedicatee of "Cloud Orchid" (44). The poet feels empathy with his lost friend to whom he had already dedicated the poem "Badger" in the collection An Exploded View published in 1973: "Ours was a language of flowers" (44). Elsewhere a lady friend and poet, Dorothy Molloy, whose first collection of poems Hare Soup was published just before her death in 2004, is the dedicatee of the poem "Holly Bush": "Your first and last slim volume. Dorothy, / You read your poems just once and I was there" (22).

The poem "The Poker" pays homage to Michael Longley's late twin brother, Peter, ${ }^{3}$ apprenticed at the same Belfast shipyards as Sam Thompson, the trade-unionist who denounced sectarianism and political corruption in the 50s and 60s in his two plays, Over the Bridge and Cemented with Love. The poem

2. His paintings, Piper's Flowers, were published in 1987 by Blackstaff Press. The Wellington Park Hotel, close to Queens' University, where Piper used to lunch has a permanent exhibition of his work.

3. The poet has dedicated several poems to the memory of his twin brother in his tenth collection, The Stairwell, published in 2014. 
concludes on these two lines: "Shall I polish my brother's poker? / It's precious, Sam. It belongs to you" (31). Another character, Lena Hardy, who looked after the poet and his brother when they were babies, is the object of a two stanza-poem "Lena". The fourth line made up of three short and elliptic sentences embodies all the nostalgia and fondness of the poet for "the country girl" whom he considered as his "second mother" (Brown: 87): "She didn't die. She went away. Lena" (20).

Other poems are dedicated to living poetfriends and academics: Terence Brown, ${ }^{4}$ Maurice Harmon, ${ }^{5}$ Eddie Linden, ${ }^{6}$ poems which were published in celebration of these distinguished people as birthday presents. The sixteenth-century elegist Chidiock Tichborne who wrote his unique "Elegy", just before dying on the gallows for conspiring against Queen Elizabeth I, is mentioned in the poem "Once": "Castration, disembowelment, / A smile on his face surely" (36), Longley teasingly inviting Maurice Harmon to write a unique poem, too.

The best example of longevity would be the American poet Stanley Kunitz ${ }^{7}$ who died at the

4. Terence Brown, Professor of Anglo-Irish Literature at Trinity College Dublin from 1993 to his retirement in 2009. Among other publications, he is the author of the influential Ireland: A Social and Cultural History, 1922 to the Present (2004). A collection of poems and essays in his honour by some of Ireland's leading scholars and writers was published in 2007, among which was Longley's poem.

5. Maurice Harmon, Emeritus Professor of AngloIrish Literature at U.C.D. Dublin, is a distinguished critic, biographer, editor, literary historian, poet, and the author of numerous publications. As Longley writes in the Afterword, the poem "Once" appeared in Honouring the Word. Celebrating Maurice Harmon on the occasion of his $80^{\text {th }}$ birthday published in 2010 .

6. Eddie Linden, who was born in Northern Ireland in 1935 and left for London in 1958 after a tragic early life, founded a periodical Aquarius, dedicated to poetry. Eddie's Own Aquarius was published in 2005 to mark his $70^{\text {th }}$ birthday. By all accounts, Linden was a man literally saved by literature.

7. Author of Passing through. The Later Poems (1995), winner of the National Book Award, and The Wild Braid. A Poet reflects on a century in the Garden (2005) age of a hundred, not long after Longley's visit in Manhattan in 2006. As he was also an accomplished gardener, both of them took time to discuss the beauty of his flowers in the twenty-eight lines, one-stanza poem entitled "Visiting Stanley Kunitz" whose very short lines of six syllables reflect a conversational, slightly breathless tone:

\section{Cuddling up, we talk about \\ Flowers, important things, \\ And hold hands to celebrate \\ Spring gentian's heavenly \\ (Strictly speaking) blue. (35)}

This poem echoes another entitled "Gardening in Cardoso" (23) where the poet himself is busy weeding, for nature is also competing with mankind. It becomes a matter of life and death: "I cut back the wild fig tree, / Its roots under the casa / Squeezing our water pipes." (23)

Other people whose absence is commemorated but who are not explicitly named or who were neighbours or relatives of the poet - "Pamela", "Missing Marie", "Mary O'Toole", "Sister Agnes" - , remain living presences in the memory of the writer and the reader too. The quatrain entitled "Helen" is devoted to the memory of the Czech-born survivor of Auschwitz, Helen Lewis, who lived on Lisburn Road in Belfast and died in 2010. She had already been the subject of "A Linen Handkerchief" in the collection The Weather in Japan published in 2000 and "Two Skunks" in Snow Water. The poem "Helen", in which the word "snow" is repeated three times as a metaphor for death and the vanishing of all traces of atrocities such as "Those terrible numbers above your wrist" (43), directly precedes a poem which alludes to Edward Thomas's writing: "Bud clusters, the making of snow in May/ October sunshine, and a blaze of hard-hearted / Haws in the Aughawillan hedge" (43).

Significantly, these poems are framed by others in which Michael Longley's six grandchildren are celebrated as symbols of the future and the (temporary) triumph of life over death. These poems sound more like lullabies this time. The sonnet "A Mobile for Maisie" is placed just after the sonnet commemorating the memory of Colin Middleton as a sort of mirror. The continuity from the several generations that have led to the birth of Longley's sixth grand- 
child is embodied in the kilt worn by Longley's father on the Great War's front and the other kilt being sewn by Maisie's father next door, these two references to the new-born's ancestors being put within brackets as a reminder. For the whole collection is pervaded by the passing of time and its inexorable consequence on the human condition. The undying character of love is proclaimed in the face of destiny - "we are lovers still" (18) -, but emphasis is put on the fact that decades lie behind the lovers which cannot be recovered: "Can you go on smiling from your dune-throne / With your hair and hands full of summer flowers?" (19), such is the poet's wistful reflection on contemplating from his sick bed a photograph of "her" taken almost forty years before. Nature around is getting older too, maybe the "elderly beech" (6) close to their cottage in Carrigskeewaun will continue expanding when both are gone. For there is no turning back of the clock, and the future is therefore "writ in white spaces", a verse by the American poet Barbara Guest ${ }^{8}$ put as an epigraph to A Hundred Doors.

\section{Nature and Nurture}

At the end of the day, the poet considers himself as a survivor in the face of the growing list of friends and relatives who are no more, even the "ideal death" he had dreamed of in Charlie Gaffney's pub in Louisburgh, has been stolen from him: "But it's Charlie Gaffney / Who has died" (20) in the poem entitled "The Lifeboat". The rupture in rhythm between the second and the third stanzas point to this unexpected death which leaves the poet without answer to his questions. Louisburgh, like Carrigskeewaun, or Innishdeigil, are places which have become a favourite haunt of the poet since time immemorial and are part of Longley's preoccupations with his environment, which he considers to be more and more in danger of disappearing.

As he declared in an interview: "the poet is part of nature. Language is part of nature" (Randolph: 307). In an article published in 2013,

8. This line concludes the poem "Noisetone", included in Collected Poems, edited by Hadley Haden Guest, two years after her mother's death at the age of 85 in 2006 (Wesleyan University Press, 2008), p. 471.
Meg Tyler examines Longley's relationship to the pastoral and argues that it is "relief but not simplicity or isolation", which the poet finds in it. More significantly perhaps, Elmer KennedyAndrews has analysed the role played by natural surroundings in Longley's writing: "In the animal and vegetative world of Longley's poetry, the poem is viewed as process, its rhetorical patterns arising organically, as do the patterns in nature, both the poem and the nature its reflects being living systems" (KennedyAndrews 2008: 150).

Edward Thomas's poetry could be defined as the link between war and nature, Longley seemingly having special affinities with it; though he remains aware of Thomas's probable delusions as regards his own aspiration, as the concluding lines of the elegy entitled "Edward Thomas's Poem" in Snow Water dating from 2004 testify: "The nature poet turned into a war poet as if / He could cure death with the rub of a dock leaf" (Longley 2004: 307). Indeed, Edward Thomas died from shell shock at the Battle of Arras during the spring of 1917, a bloody suicidal offensive led by a combination of French, British and Canadian forces against the Germans. He was buried nearby in the military cemetery of Agny and his cross bears the inscription "poet", a fact which is unusual as many graves have none at all. The poem "Vimy Ridge" is devoted to him, a four-line stanza which ends thus: "Between the terrific noises of the guns I / Can hear two hedge sparrows making love"" (39). This is a quotation from Thomas's war diary, which the poet, on behalf of his wife Edna, had consulted in the Berg Collection in the New York Public Library, having had difficulty deciphering Thomas's minuscule handwriting.

The most important theme of Longley's poetry is indeed that of Nature, a theme that encapsulates all his philosophy of life and whose emblematic place is Carrigskeewaun in the West of Ireland in the county of Mayo, all the more so since, as he declared in 2003, "Carrigskeewaun provides me with the template of experiencing all other places and keeps me sensitive, I hope, to the nuances of locality" (Randolph: 307). In "The Wren", he even remarks that he is "writing too much about Carrigskeewaun" (7). But this "soul landscape", as he declared in a recent broadcasting on the B.B.C, ${ }^{9}$ is also now the 
place where his grandchildren come to spend some time, and whom he feels entitled to teach about ornithology and botany. Significantly, the world of nature also encapsulates man's world with its violence. The poem "The Leveret" which had already been published in Collected Poems two years before is dedicated to one of his grandsons and the poet tries to reassure him as regards the struggle for life inside nature:

We may meet the stoat near the erratic

Boulder, a shrew in his mouth, or the merlin

Meadow-pipit-hunting. But don't be afraid. (5)

The collection A Hundred Doors starts and ends in Carrigskeewaun, County Mayo: "a townland with just one cottage". In the first poem entitled "Call", the poet is absent and wonders whether to call his friend who is spending "the millennium" there. In the last poem entitled "Greenshank", he muses about his own definitive departure and asks his reader to remember him when hearing the call of the greenshank. The tone is also muted, as he wonders whether nature will still be intact, maybe the lake will have disappeared. Indeed, the greenshank, a migratory bird with dark grey back, long green legs, a slightly turned up beak, is mentioned for the first time in Longley's poetry, and all that would remain of the poet would be its "estuarial fluting" (48).

In all the poems mentioned, it seems that God has deserted the world and the three poems devoted to places of religion and worship are seemingly bereft of any humanity or sympathy. The poet finds himself victimized by "a xenophobic / Sacristan" (15) in the "Lady of a Hundred Doors", while the Cathedral of Ely, known locally as "The ship of the Fens", is compared to "a gigantic ledger / Crammed with the names of unremembered soldiers / Under their village names" in the poem "Wooden Sails" (40). Quite significantly, the poem on the facing page, "Altarpiece", relates the near miss

9. Paul Farley, "City Streets and Sea Shores", BBC radio4, Sunday 10 Nov. 2013 (bbc.co.uk/ programmes/bO3gtvv2). This interview, interspersed with readings from new poems, took place in Carrigskewaun in unfair weather during which the journalist Paul Farley experienced some discomfort. Longley declared at one moment: "This is where I want to return, $[\ldots]$ and my ashes to be scattered... I want to be recycled in this beautiful landscape." of a German bomb on the roof of the basilica and the fear felt by the poet: "The sky is a minefield. We shall all get hurt" (41). It seems that in the future, there will still be need for more "bomb-disposal experts", a reference to the contemporary, still tense situation in his native country but also in the rest of the world. In the short four-line poem entitled "Trench Foot", Christ has been entrusted with the task of washing the feet of the soldiers, a neverending chore, and the stanza concludes ironically on his so-called "promotion" (39) after the useless butchery of the Battle of Passchendaele in Western Flanders, which had resulted in half a million casualties among the belligerents between July and November 1917.

Probably the poem that best encapsulates all the themes of A Hundred Doors is entitled "A Gust" and was written in honour of Eddie Linden's $70^{\text {th }}$ birthday. Longley significantly associates his poet-friend with Edward Thomas as well as with Pope John Paul II who had just died when the poem was written:

I'm thinking of the pope and you, Eddie,

As I dander towards the New York Public

Library to peek at the field note-books

Of Edward Thomas wandering in England

In pursuit of spring before poetry and war. (33)

The greater part of the twenty-two unrhymed pentameters of the poem are devoted to the death, in April 2005, of Pope John Paul II, who is portrayed as a mummy, musarum sacerdos, adding "(part time)" within brackets (33). The poet had allegedly encountered John Paul's ghost, up in the clouds while his plane was somewhere between Dorval and La Guardia airports. The poem ends in a tongue in cheek tone on "this bright popeless early April day", as he prepares to enter the basilica of St Peter in Rome in the wake of, or rather in company with "John Paul and Edward and Eddie Linden" (33). This entrance will take place through the Door of the Sacraments, i.e. the fourth door on the right of the main entrance of St Peter's Basilica, a door which was inaugurated in 1966 by Pope Paul VI. The absence of spirituality and sanctity is embodied in the portrait made of Pope John Paul lying puppet-like and powerless: "Now he lies still and full of chemicals / In precarious white hat and slippers / saying the rosary over and over again" (33). Significantly, the poet Eddie Linden is also a 
priest, of the Muses, but his practitioners will unite the good as well as the bad. If that windy spring day is "popeless", a sense of eternity surrounds Edward Thomas's field note-books in the library. Its pages are still riffled by a "gust" (33), as an echo throughout the years of the shell blast that killed him in the trenches of The Great War. God therefore seems to have forsaken this world and it is the poets whose work can be transmitted over the years and who can deliver a lesson of humanity and love. As Julia Kristeva wrote in Pouvoirs de l'horreur:

At that stage of discourse, power no longer rests with a God that, as a judge, would preserve mankind from abjection by taking over for himself the right to violence violence of division as well as chastisement. Power henceforth rests with discourse itself, or rather with the act of judgment expressed by speech, and in a less orthodox and much more implicit way, by all the signs (poetry, painting, music, sculpture) that depend on it (Kristeva: 154). ${ }^{10}$

10. “A cette pointe du discours, le pouvoir n'est plus au Dieu-juge qui préserve l'humanité de l'abjection en se réservant le droit à la violence pour lui seul violence de la division comme du châtiment. Le $\cdot /$.

\section{Conclusion}

In 2003, Longley expressed the following wish: "I hope there are overlappings, the nature poetry fertilizing the war poetry" (Randolph: 294). The poet often becomes something of an excavator, excavating his own past and that of his family and the past of the landscapes he loves. One of his favourite tropes, especially in the elegies, is that everything returns to nature after death, and merges into the landscape which may also be subject to change and degradation. For the composition of a poem proceeds from a reverence for the natural world but also from the choice of words - hence the lexicon of natural science -, the rhythm of the sentences - hence some poems being made of a unique sentence -, a composition akin to a religious experience in the way he "makes sense of the world", in other words, "an exploration" (Ni Anluin 2000: 125).

\footnotetext{
.\% pouvoir est désormais au discours lui-même, ou plutôt à l'acte de jugement exprimé par la parole et, de manière moins orthodoxe et beaucoup plus implicite, par tous les signes (poésie, peinture, musique, sculpture) qui en dépendent”. Translation mine.
}

\section{Works Cited}

Brown, John, ed. 2002. In the Chair: Interviews with Poets from the North of Ireland.The Cliffs of Moher: Salmon Publishings.

Girard, René. 1972. La Violence et le sacré. Paris : Grasset.

Kennedy-Andrews, Elmer. 2008. Writing Home: Poetry and Place in Northern Ireland. Woodbridge: DS Brewer.

Kristeva, Julia. 1980. Pouvoirs de l'horreur. Paris : Seuil.

Longley, Edna, ed. 2008. Edward Thomas: The Annotated Collected Poems. Tarset: Bloodaxe Books. Longley, Michael. 2000. The Weather in Japan. London: Cape. 2004. Snow Water. London: Cape. 2006. Collected Poems. London: Cape.

2011. A Hundred Doors. London: Cape.

2014. The Stairwell. London: Cape.

Longley, Michael, ed. 2013. Robert Graves: Selected Poetry. London: Faber \& Faber.

Moore, Ross. 2011. "Poetry Review: A Hundred Doors", culturenorthernireland. org, 18/05/.

Ni Anluain, Cliodhna, ed. 2000. Reading the Future. Irish Writers in Conversation with Mike Murphy. Dublin: The Lilliput Press.

Peacock, A. and Devine, K, eds. 2000. The Poetry of Michael Longley. Gerrards Cross: Colin Smythe. 
Randolph, Jody Allen. 2003. "Interview : Michael Longley", Colby Quarterly, vol.39, Issue 3.

Sloan, Barry. 2012. "Michael Longley's Father: Memory, Mourning and History", Estudios Irlandeses, Issue ${ }^{\circ}$ 7, 99-108 (http://www.estudiosirlandeses.org/wp.../05/Barry_Sloan_7.pdf.).

Tyler, Meg. 2013. “'Vespertinal Mixture': Michael Longley's A Hundred Doors”, Almatroz Poetry Journal, 1:1 (http://www. portalseer.ufba. br/revistaalmatroz/index).

Received $14^{\text {th }}$ August $2014 \quad$ Last version $25^{\text {th }}$ September 2014

Elisabeth Delattre is the author of a $\mathrm{PhD}$ thesis on the work of the novelist J.G.Farrell and of articles on Farrell, Derek Mahon, Michael Longley, Nuala O'Faolain and Ciaran Carson published in peerreviewed journals such as Etudes Irlandaises, Estudios Irlandeses or Irish Studies Review. She is a research associate with the Centre for Irish Studies, the CECILLE Centre of the University of Lille3 (http://cecille.recherche.univ-lille3/auteur/delattre-e). 